\title{
TANTANGAN PENGEMBANGAN RUMAH DATA KEPENDUDUKAN DI KABUPATEN SIDOARJO
}

\section{CHALLENGES IN DEVELOPING POPULATION DATA HOUSES IN SIDOARJO REGENCY}

\author{
Munari Kustanto ${ }^{1)^{*}}$, Fitriyatus Sholihah ${ }^{2)}$, Maslihatin Utami ${ }^{3)}$ \\ 1)Peneliti Muda pada Bappeda Kabupaten Sidoarjo, Jl. Sultan Agung No. 13 Sidoarjo \\ 2) Peneliti Pertama pada Bappeda Kabupaten Sidoarjo, JI. Sultan Agung No. 13 Sidoarjo \\ 3) Perencana Pertama pada Bappeda Kabupaten Sidoarjo, JI. Sultan Agung No. 13 Sidoarjo \\ *e-mail: munarikustanto@gmail.com
}

\section{Submit : 29 April 2020 ; Revisi : 28 Juli 2020 ; Terbit : 29 Juli 2020}

\begin{abstract}
Population data plays an important role to succeed in the development regencies, including in Sidoarjo Regency. The valid and accountable population data is an absolute requirement that development policies are right on target, ranging from providing assistance to setting targets and development programs. Using a descriptive qualitative approach, this study aims to evaluate the condition of the Population Data House (Rumah Dataku) in Sidoarjo Regency as well as to identify the challenges of its development, both internal and external. The results showed that of the 353 villages in the Sidoarjo regency, there were only 42 villages / kelurahan (11.90\%) having a KB (Family Planning) village. Of this number, not all of them had a Dataku House. There were only three KB villages (7\%) that had Dataku Houses. Viewed from the aspect of availability, presentation and updating of existing data, the $K B$ Villages and Dataku Houses in Sidoarjo Regency have not shown good performance. The internal and external challenges faced in developing Dataku Houses in Sidoarjo Regency included the budget constraints, limited resources (human resources and supporting infrastructure), lack of coordination, and lack of community understanding and participation. The Sidoarjo Regency Government may overcome these challenges through organizing a KB Village competition and a Thematic Community Service Program, making an application for the Dataku House, increasing the role of the KB Village Working Group, and training for KB management and extension workers.
\end{abstract}

Keywords: KB village, development, Rumah Dataku

\begin{abstract}
ABSTRAK
Data kependudukan memiliki peranan penting bagi keberhasilan pembangunan di suatu daerah, termasuk di Kabupaten Sidoarjo. Data kependudukan yang valid dan dapat dipertanggungjawabkan menjadi syarat mutlak agar kebijakan pembangunan tepat sasaran, mulai dari pemberian bantuan hingga penentuan sasaran dan program pembangunan. Menggunakan pendekatan deskriptif kualitatif, penelitian ini bertujuan mengevaluasi kondisi Rumah Data Kependudukan (Rumah Dataku) di Kabupaten Sidoarjo sekaligus mengidentifikasi tantangan pengembangannya, baik internal maupun eksternal. Hasil penelitian menunjukkan bahwa dari 353 Desa/Kelurahan yang ada di Kabupaten Sidoarjo, tercatat hanya 42 Desa/Kelurahan (11,90\%) yang telah memiliki kampung KB. Dari jumlah tersebut tidak semuanya memiliki Rumah Dataku, tercatat hanya tiga Kampung KB (7\%) yang telah memiliki Rumah Dataku. Dilihat dari aspek ketersediaan, penyajian dan keterbaharuan data yang ada Kampung KB dan Rumah Dataku di Kabupaten Sidoarjo belum menunjukkan kinerja yang menggembirakan. Tantangan internal dan eksternal yang dihadapi dalam pengembangan Rumah Dataku di Kabupaten Sidoarjo antara lain: keterbatasan anggaran, keterbatasan sumber daya (sumber daya manusia dan sarana prasarana pendukung), belum optimalnya koordinasi, serta kurangnya pemahaman dan partisipasi masyarakat. Beberapa upaya yang dapat ditempuh Pemerintah Kabupaten Sidoarjo untuk mengatasi tantangan tersebut antara lain mengadakan kompetisi Kampung KB, menyelenggarakan KKN Tematik, membuat aplikasi untuk Rumah Dataku, meningkatkan peran Pokja Kampung KB, hingga pelatihan untuk pengurus dan penyuluh KB.
\end{abstract}

Kata kunci: Kampung KB, Pengembangan, Rumah Dataku 


\section{PENDAHULUAN}

Perkembangan kependudukan dan pembangunan keluarga menjadi salah satu isu penting dalam pembangunan berkelanjutan di Indonesia. Perencana pembangunan selalu berupaya mewujudkan perbandingan yang ideal antara perkembangan kependudukan dengan daya dukung dan daya tampung lingkungan. Harapannya pemenuhan kebutuhan generasi di masa sekarang tidak mengganggu kemampuan dan kebutuhan di masa mendatang.

Masalah kependudukan di Indonesia selalu membawa implikasi bagi kehidupan baik di bidang sosial, ekonomi, politik hingga pertahanan keamanan. Secara kuantitas, jumlah penduduk yang besar tentu menimbulkan permasalahan dalam penyediaan sandang, pangan dan papan. Adapun secara kualitas, keberadaan penduduk akan berpengaruh kepada daya saing Indonesia.

Sebagai obyek sekaligus subyek pembangunan, penduduk dikenali, diidentifikasi, dipilah dan dianalisis agar kebijakan pembangunan yang diterapkan dapat tepat sasaran. Data dan informasi kependudukan dengan demikian memainkan peranan yang sangat penting. Melalui UndangUndang Nomor 52 Tahun 2009 tentang Perkembangan Kependudukan dan Pembangunan Keluarga, Pemerintah dan Pemerintah Daerah diberikan amanat untuk mengumpulkan, mengolah dan menyajikan data dan informasi mengenai kependudukan dan keluarga. Upaya tersebut dapat dilakukan melalui sensus, survei dan pendataan keluarga. Meskipun demikian, hingga saat ini penyediaan data yang terkait dengan perencanaan pembangunan, termasuk data kependudukan dan keluarga masih belum terwujud.
Menyadari hal di atas dan sekaligus menindaklanjuti regulasi tersebut, Badan Kependudukan dan Keluarga Berencana Nasional meluncurkan Program Kependudukan, Keluarga Berencana dan Pembangunan Keluarga (KKBPK). Salah satu wujud implementasi dari program tersebut adalah pembentukan Kampung KB yang dimulai pada awal tahun 2016. Salah satu prasyarat penting bagi pendirian Kampung KB adalah ketersediaan data dan indikator pembangunan yang terkini, valid dan dapat dipercaya. Dalam upaya memenuhi kebutuhan tersebut, Direktorat Analisis Dampak Kependudukan mengembangkan model yang dikenal dengan Rumah Data Kependudukan (BKKBN, 2018).

Sebagai bagian dari Negara Kesatuan Republik Indonesia, Pemerintah Kabupaten Sidoarjo terus melakukan upaya untuk mendukung pengembangan Kampung KB. Meskipun demikian, perkembangannya masih belum memuaskan. Tercatat sebanyak 43 Kampung KB yang terbentuk di Kabupaten Sidoarjo sejak dicanangkan tahun 2016 (Wijayanto, 2019). Jumlah ini relatif sedikit jika dibandingkan dengan 353 Desa/Kelurahan yang ada di Kabupaten Sidoarjo.

Memperhatikan kondisi tersebut, Pemerintah Kabupaten Sidoarjo bertekad untuk terus mengembangkan keberadaan Kampung KB. Sebagaimana dijelaskan sebelumnya, Rumah Data Kependudukan merupakan salah satu pilar penting bagi pengembangan Kampung KB. Dengan demikian, salah satu hal yang patut menjadi perhatian adalah kehadiran Rumah Data Kependudukan, yang dikenal dengan "Rumah Dataku".

Tanpa adanya data yang berbasis kependudukan dan keluarga, 
maka

dapat

dipastikan

Desa/Kelurahan sebagai ujung tombak pelayanan di Kabupaten Sidoarjo akan mengalami banyak kendala, khususnya bagi pelaksanaan program dan kegiatan yang menjadikan keluarga sebagai target sasaran. Contohnya adalah pemberian bantuan yang acapkali menimbulkan gejolak di masyarakat. Inclusion and exclusion error menjadi masalah klasik yang acapkali ditemui di lapagan.

Penelitian dengan tema Kampung KB sudah cukup banyak dilakukan. Salah satunya adalah penelitian Evaluasi Program Kampung Keluarga Berencana di Kota Denpasar. Dengan menggunakan pendekatan deskriptif kualitatif, penelitian ini mengevaluasi pelaksanaan program Kampung KB di Kota Denpasar. Hasil penelitiannya menunjukkan bahwa program Kampung KB sudah cukup baik jika dilihat dari indikator efektivitas, kecukupan, responsivitas, dan ketepatan. Meskipun demikian, dari indikator efisiensi dan perataan hasilnya masih belum optimal (Mardani, Winaya, \& Purnamaningsih, 2020).

Penelitian lain mengupas tentang implementasi program Kampung Keluarga Berencana. Pendekatan yang digunakan oleh Nurjannah \& Susanti (2018) dalam penelitiannya adalah mix method Penelitian ini bertujuan untuk mengetahui gambaran implementasi program dan kendala pelaksanaan kegiatan Kampung KB. Hasil penelitian menunjukkan bahwa implementasi program Kampung KB di Kabupaten Kuningan secara umum berjalan dengan baik. Terjadi peningkatan aksesptor KB dari 5.244 akseptor menjadi 5.519 akseptor setelah dilaksanakan program Kampung KB. Beberapa kendala yang dihadapi antara lain kurang antusiasnya masyarakat, kurangnya pemahaman, dan kurangnya koordinasi.

Penelitian terkait implementasi program Kampung KB di Kabupaten Sidoarjo juga telah dilakukan. Salah satunya adalah penelitian yang dilakukan oleh Bachtiyar dan Wibawani (2017). Penelitian ini bertujuan mendeskripsikan dan menganalisis implementasi program Kampung KB di Dusun Ambeng-Ambeng Desa Ngingas Kecamatan Waru Kabupaten Sidoarjo dengan menggunakan pendekatan kualitatif deskriptif. Hasil penelitian ini menunjukkan bahwa secara umum implementasi program Kampung KB telah berjalan dengan baik. Meski demikian, terdapat satu kegiatan yang belum terlaksana, yaitu Pusat Informasi Konseling (PIK) Remaja.

Berbeda dengan penelitianpenelitian sebelumnya yang lebih memfokuskan pembahasan pada program Kampung $\mathrm{KB}$, penelitian ini lebih berfokus pada evaluasi Rumah Data Kependuduk (Rumah Dataku). Selain itu, lokasi penelitian ini mencakup seluruh kecamatan di Kabupaten Sidoarjo. Dengan demikian, penelitian ini berupaya mengisi kekosongan yang masih ditinggalkan penelitian sebelumnya.

Selayaknya sebuah organsiasi, pengembangan Rumah Dataku merupakan sebuah proses yang melibatkan penerapan pengetahuan dan praktek ilmu perilaku untuk membantu organisasi meraih tingkat efektivitas yang tinggi (Sulaksana, 2004). Faktor terbesar yang mempengaruhi kehidupan organisasi adalah faktor internal dan faktor eksternal. Faktor internal adalah perkembangan yang terjadi di dalam organisasi sendiri, sedangkan faktor eksternal merupakan dampak dari perkembangan lingkungan (Istianda, 
Wulandari, Purwanto, Putra, \& Darmanto, 2014).

Tantangan pengembangan Rumah Dataku di Kabupaten Sidoarjo dengan demikian mengacu kepada kedua faktor di atas. Tantangan internal dan eksternal inilah yang akan menjadi kunci bagi upaya pengembangan Rumah Dataku di Kabupaten Sidoarjo.

\section{METODE}

Penelitian dilakukan pada bulan November hingga Desember 2019. Penelitian ini termasuk dalam penelitian eksploratif. Berdasarkan pendekatan yang digunakan, penelitian ini penelitian deskriptif kualitatif. Pendekatan ini dianggap relevan untuk menggali tantangan pengembangan Rumah Dataku di Kabupaten Sidoarjo.

Subyek dalam penelitian ini adalah pengurus Rumah Dataku yang dipilih secara pusposive pada Kampung KB di Kabupaten Sidoarjo. Apabila Kampung KBnya belum memiliki Rumah Dataku, maka responden adalah pengurus Kampung KB yang memiliki keterkaitan dengan pengelolaan data kependudukan.

Jenis data yang digunakan dalam penelitian ini merupakan data primer dan data sekunder. Data primer diperoleh melalui kuesioner terhadap pengurus Rumah Dataku atau pengurus Kampung KB yang ada di Kabupaten Sidoarjo. Adapun data sekunder diperoleh dari Dinas Pemberdayaan Perempuan Perlindungan Anak dan Keluarga Berencana (DP3AKB) Kabupaten Sidoarjo. Data yang sudah terkumpul kemudian dianalisa secara kualitatif.
HASIL DAN PEMBAHASAN

\section{Gambaran Kampung KB dan Rumah Data Kependudukan di Kabupaten Sidoarjo}

Sebagai

pusat

data kependudukan pada level mikro, Rumah Dataku memiliki tujuan antara lain : (i) meningkatkan kepedulian dan peran serta masyarakat dan mitra kerja dalam pengelolaan data kependudukan level mikro di Kampung $\mathrm{KB}$; (ii) meningkatkan kesadaran masyarakat tentang pentingnya data dan informasi untuk peningkatan pengetahuan, sikap dan perilaku yang berwawasan kependudukan; (iii) meningkatkan sinergitas komponen BKKBN dan mitra kerja dalam penyediaan dan pemanfaatan data dan informasi untuk intervensi berbagai permasalahan kependudukan; dan (iv) meningkatkan modal sosial, wahana belajar dan berinteraksi masyarakat (Mardiya, 2019).

Informasi dari Dinas P3AKB Kabupaten Sidoarjo, sampai dengan tahun 2019 terdapat 42 Kampung KB yang tersebar di 18 Kecamatan. Apabila dibandingkan dengan 353 Desa/Kelurahan yang ada di Kabupaten Sidoarjo, maka jumlah Kampung KB di Kabupaten Sidoarjo tercatat hanya $11,90 \%$. Kondisi ini tentunya memerlukan perhatian serius dari Pemerintah Kabupaten Sidoarjo. Hal ini tidak terlepas dari peran penting Kampung KB dalam mendukung perencanaan pembangunan berperspektif kependudukan.

Tugas Pemerintah Kabupaten Sidoarjo dalam mengembangkan Kampung KB tentunya tidak dapat terlepas dari keberadaan Rumah Dataku yang menjadi salah satu prasyarat penting. Apabila menilik kondisi Rumah Dataku yang ada sekarang, maka Pemerintah Kabupaten Sidoarjo memiliki tugas yang tidak ringan. Dari 42 Kampung 
KB yang ada di Kabupaten Sidoarjo, ternyata tidak semuanya memiliki Rumah Dataku.

Berdasarkan data yang berhasil dihimpun hanya terdapat tiga Kampung KB yang telah memiliki Rumah Dataku. Diagram di bawah ini memperlihatkan posisi relatif Rumah Dataku terhadap Kampung KB di Kabupaten Sidoarjo.

Diagram 1. Posisi Relatif Rumah Dataku Terhadap Kampung KB di Kabupaten Sidoarjo Tahun 2019

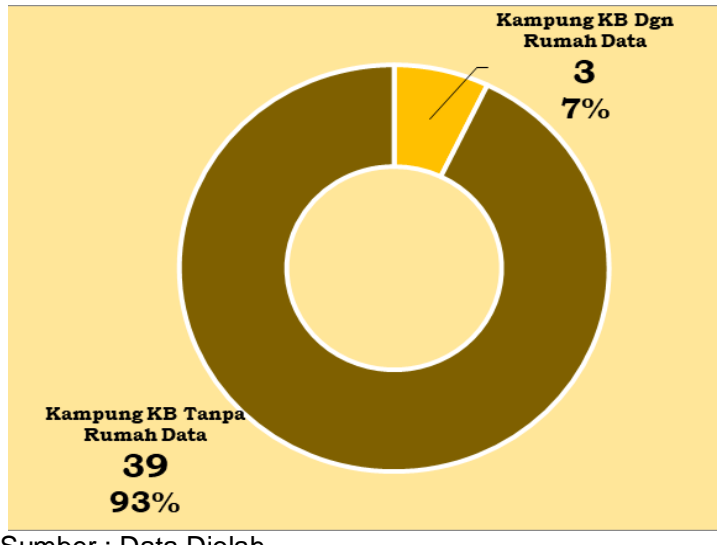

Sumber : Data Diolah

Tercatat hanya 7\% Kampung KB di Kabupaten Sidoarjo yang telah memiliki Rumah Dataku. Ketiga Kampung KB tersebut adalah Rumah Data Krajan di Desa Waru Kecamatan Waru, Rumah Data Gelang di Desa Gelang Kecamatan Tulangan, dan Rumah Data Grogol di Desa Grogol Kecamatan Tulangan. Sisanya sebanyak 39 Kampung KB di Kabupaten Sidoarjo tidak memiliki Rumah Data Kependudukan.

Kondisi ini tentunya cukup menarik untuk dicermati sebab sebagaimana keberadaan Rumah Dataku merupakan prasyarat penting bagi keberadaan Kampung KB. Fenomena yang terjadi di Kabupaten Sidoarjo adalah sebaliknya. Menilik banyaknya Kampung KB yang tidak memiliki Rumah Data Kependudukan, maka secara tidak langsung dapat diasumsikan bahwa pendirian
Kampung KB tidak sesuai dengan ketentuan yang ada.

Memperhatikan kondisi di atas, maka salah satu hal penting yang dapat dilakukan Pemerintah Kabupaten Sidoarjo adalah mendorong pembentukan Rumah Dataku. Prioritas utama tentunya pada 39 Kampung KB yang telah berdiri tetapi belum memiliki Rumah Dataku. Tanpa adanya dukungan data yang berkualitas, keberadaan Kampung KB kurang memberikan dampak. Hal ini pula yang diindikasikan sebagai salah satu penyebab tidak berkembangnya Kampung KB di Kabupaten Sidoarjo.

Tanpa ketersediaan data yang valid dan up to date, Kampung KB tidak dapat menjalankan perannya dengan optimal. Salah satunya adalah ketidakmampuan mengidentifikasi dan mendeteksi potensi permasalahan kependudukan di masyarakat. Mengingat perannya yang penting, Pemerintah Kabupaten Sidoarjo perlu mendorong keberadaan Kampung KB beserta Rumah Dataku.

Kalau dianalisi dari aspek kepengurusan Kampung KB di Kabupaten Sidoarjo, ada temuan yang menarik. Meskipun secara riil hanya terdapat tiga Rumah Data Kependudukan dari 42 Kampung KB yang ada, Kampung KB yang tidak memiliki Rumah Data Kependudukan ternyata telah memiliki struktur organisasi dan pengurusnya.

Panduan Rumah Data Kependudukan di Kampung KB yang dirilis oleh Direktorat Analisis Dampak Kependudukan Badan Kependudukan dan Keluarga Berencana Nasional menyebutkan bahwa Rumah Dataku memiliki struktur organisasi yang terdiri dari Ketua, Wakil Ketua, Seksi Pengumpulan dan Pemutakhiran Data, Seksi Pengolahan dan Analisis Data, Seksi Pelayanan dan Pemanfaatan Data, serta Seksi Operasional Rumah 
Data. Berdasarkan data yang berhasil dihimpun, terdapat 33 Kampung KB yang memiliki kepengurusan Rumah Dataku dengan lengkap; sisanya sebanyak sembilan Kampung KB belum memiliki kepengurusan Rumah Dataku dengan lengkap.

Kelengkapan kepengurusan ternyata tidak menjamin ketersediaan data pada Rumah Dataku maupun Kampung KB. Informasi yang berhasil diperoleh menunjukkan bahwa data yang ditampilan umumnya data hasil penelitian pihak ketiga. Dalam hal ini adalah data yang dipegang oleh petugas penyuluh KB yang tersebar di 18 Kecamatan.

Rumah Dataku setidaknya harus menyediakan 36 elemen data yang terbagi dalam lima ruang lingkup data. Kelima ruang lingkup data tersebut antara lain Data Pendataan Keluarga, Data Potensi Desa, Data Sektoral, Data Aktivitas Kampung KB, dan Data Administrasi Kependudukan. Terdapat tiga aspek yang akan dideskripsikan yaitu, aspek ketersediaan, aspek penyajian, dan aspek keterbaharuan (updating).

Ketersediaan data pada Kampung KB yang ada di Kabupaten Sidoarjo secara umum menunjukkan hasil yang juga bervariasi. Dari 36 elemen data yang harusnya tersedia, tidak semuanya mampu disediakan oleh Kampung KB. Elemen data Jumlah Penduduk Berumur 5 Tahun $\mathrm{Ke}$ atas Menurut Wilayah dan Kemampuan Membaca dan Menulis tercatat paling sedikit disediakan. Hanya 17 Kampung KB atau 40,48\% dari 42 Kampung KB yang mampu menyediakan elemen data tersebut.

Elemen data Jumlah PUS Peserta KB Berdasarkan Metode Kontrasepsi Yang Sedang Digunakan dan Jumlah PUS Berdasarkan Kesertaan Ber-KB tercatat paling banyak disediakan. Hampir seluruh
Kampung KB mampu menyediakan kedua elemen data tersebut. Kedua elemen data tersebut tersedia di 41 Kampung KB atau 97,62\%.

Elemen data yang terkait dengan Data Sektoral dan Data Administrasi Kependudukan paling sedikit tersedia di Kampung KB. Adapun elemen data yang terkait dengan Data Pendataan Keluarga tercatat paling banyak tersedia pada Kampung KB. Kondisi ini tentu tidak terlepas dari peran dan fungsi yang diemban oleh Kampung $\mathrm{KB}$.

Apabila dilihat lebih detail lagi pada masing-masing Rumah Dataku yang ada, Rumah Data Krajan memiliki ketersediaan data yang cukup tinggi. Tercatat sebanyak 33 elemen data atau $91,67 \%$ yang tersedia. Sebaliknya, Rumah Data Gelang memiliki ketersediaan data paling rendah yaitu, sebanyak 16 elemen data atau 44,44\%. Adapun Rumah Data Grogol memiliki ketersediaan data yang cukup. Tercatat sebanyak 26 elemen data atau $72,22 \%$ telah tersedia.

Dilihat dari ruang lingkup data yang tersedia pada Rumah Dataku, ketiganya memiliki karakteristik yang berbeda.

Tabel 1

Komposisi Ketersediaan Elemen Data pada Rumah Data Kependudukan di Kabupaten Sidoarjo Berdasarkan Ruang Lingkup Data Tahun 2019

\begin{tabular}{|c|c|c|c|c|}
\hline \multirow[b]{2}{*}{$\begin{array}{c}\text { Ruang Lingkup } \\
\text { Data }\end{array}$} & \multicolumn{4}{|c|}{ Jumlah Ketersediaan Elemen Data } \\
\hline & Standar & $\begin{array}{l}\text { RD } \\
\text { Krajan }\end{array}$ & $\begin{array}{l}\text { RD } \\
\text { Gelang }\end{array}$ & $\begin{array}{c}\text { RD } \\
\text { Grogol }\end{array}$ \\
\hline $\begin{array}{l}\text { Data } \\
\text { Pendataan } \\
\text { Keluarqa }\end{array}$ & 21 & 20 & 8 & 17 \\
\hline $\begin{array}{l}\text { Keluarga } \\
\text { Data Potensi } \\
\text { Desa }\end{array}$ & 3 & 2 & 0 & 2 \\
\hline Data Sektoral & 6 & 6 & 4 & 4 \\
\hline $\begin{array}{l}\text { Data Adm. } \\
\text { Kependudukan }\end{array}$ & 6 & 5 & 4 & 3 \\
\hline Jumlah & 36 & 33 & 16 & 26 \\
\hline
\end{tabular}

tabel di atas menunjukkan bahwa ketersediaan elemen data pada Rumah Data Krajan merupakan yang terbaik untuk semua ruang lingkup 
data. Bahkan pada ruang lingkup data sektoral, Rumah Data Krajan mampu menyediakan semua elemen data yang dibutuhkan. Adapun Rumah Data Gelang terlihat masih belum menunjukkan kinerja yang baik dalam penyediaan elemen data pada masingmasing ruang lingkup. Dilihat dari ruang lingkup data potensi desa, Rumah Data Gelang belum menyediakannya sama sekali.

Selanjutnya akan disampaikan gambaran mengenai penyajian data. Secara keseluruhan penyajian data pada Kampung KB yang ada di Kabupaten Sidoarjo menunjukkan hasil yang juga bervariasi. Dari 36 elemen data yang harusnya disajikan baik dalam bentuk tabulasi, diagram, maupun grafik, ternyata tidak semuanya mampu disajikan oleh Kampung KB.

Elemen data Jumlah Penduduk Berumur 5 Tahun $\mathrm{Ke}$ atas Menurut Wilayah dan Kemampuan Membaca dan Menulis tercatat paling sedikit disajikan. Hanya terdapat 16 Kampung KB atau 38,10\% dari 42 Kampung KB yang mampu menyajikan elemen data tersebut. Sebaliknya elemen data Jumlah Kelahiran, Kematian dan Migrasi Penduduk tercatat paling banyak disajikan. Tercatat elemen data tersebut mampu disajikan oleh 31 Kampung KB atau 73,81\%.

Elemen data yang terkait dengan Data Sektoral dan Data Potensi Desa paling sedikit disajikan oleh Kampung $\mathrm{KB}$. Adapun elemen data yang terkait dengan Data Pendataan Keluarga tercatat paling banyak disajikan oleh Kampung KB. Bentuk penyajian data yang paling banyak dilakukan oleh Kampung KB adalah tabulasi. Dari 36 elemen data yang harus disediakan seluruhnya disajikan dalam bentuk tabulasi.

Data tersebut ternyata tidak diolah lebih lanjut oleh pengelola
Kampung KB. Hal ini terlihat dari jumlah elemen data yang disajikan dalam bentuk diagram maupun grafik. Tercatat hanya 25 elemen data $(69,44 \%)$ yang disajikan dalam bentuk diagram. Bahkan elemen data yang disajikan dalam bentuk grafik hanya tercatat empat elemen data $(11,11 \%)$.

Kondisi tersebut tentu perlu mendapat perhatian dari Pemerintah Kabupaten Sidoarjo. Penyajian data dalam bentuk diagram maupun grafik tentunya akan lebih mudah untuk diinterpretasi. Harapannya melalui interpretasi tersebut dapat teridentifikasi berbagai permasalahan kependudukan sehingga dapat cepat pula dirumuskan intervensinya.

Masing-masing Rumah Dataku yang ada, jika dilihat lebih detail lagi, menunjukkan kondisi yang bervariasi. Rumah Data Krajan memiliki penyajian data yang cukup tinggi. Sebanyak 33 elemen data $(91,67 \%)$ telah disajikan, meskipun semuanya dalam bentuk tabel. Sebaliknya, Rumah Data Gelang tercatat memiliki penyajian data paling rendah. Tercatat hanya 15 elemen data $(41,67 \%)$ yang mampu disajikan. Adapun Rumah Data Grogol memiliki penyajian data yang cukup, 26 elemen data $(72,22 \%)$ telah disajikan.

Dilihat dari ruang lingkup data yang disajikan pada Rumah Dataku, ketiganya memiliki karakteristik yang berbeda.

Tabel 2

Komposisi Penyajian Elemen Data pada

Rumah Dataku di Kabupaten Sidoarjo Berdasarkan Ruang Lingkup Data Tahun 2019

\begin{tabular}{|lcccc|}
\hline \multicolumn{1}{c}{$\begin{array}{c}\text { Ruang Lingkup } \\
\text { Data }\end{array}$} & \multicolumn{4}{c|}{ Jumlah Elemen Data Yang Disajikan } \\
\cline { 2 - 5 } & Standar & $\begin{array}{c}\text { RD } \\
\text { Krajan }\end{array}$ & $\begin{array}{c}\text { RD } \\
\text { Gelang }\end{array}$ & $\begin{array}{c}\text { RD } \\
\text { Grogol }\end{array}$ \\
\hline $\begin{array}{l}\text { Data } \\
\begin{array}{l}\text { Pendataan } \\
\text { Keluarga }\end{array}\end{array}$ & 21 & 20 & 7 & 17 \\
$\begin{array}{l}\text { Data Potensi } \\
\begin{array}{l}\text { Desa } \\
\text { Data Sektoral }\end{array}\end{array}$ & 3 & 2 & 0 & 2 \\
$\begin{array}{l}\text { Data Adm. } \\
\text { Kependudukan }\end{array}$ & 6 & 6 & 5 & 4 \\
\hline Jumlah & 36 & 5 & 3 & 3 \\
\hline
\end{tabular}

Sumber : Data Diolah 
Memperhatikan tabel di atas, penyajian elemen data pada Rumah Data Krajan masih yang terbaik untuk semua ruang lingkup data. Bahkan pada ruang lingkup data sektoral, Rumah Data Krajan mampu menyajikan semua elemen data yang dibutuhkan. Sebaliknya, Rumah Data Gelang terlihat masih belum menunjukkan kinerja yang baik dalam penyajian elemen data pada masingmasing ruang lingkup, terlebih pada ruang lingkup data potensi desa yang belum tersaji sama sekali.

Melihat aspek keterbaharuan data, secara keseluruhan kebaharuan data pada Kampung KB yang ada di Kabupaten Sidoarjo juga menunjukkan hasil yang bervariasi. Belum semua elemen data mampu diperbaharui/ diupdate oleh Kampung KB. Keberadaan elemen data yang tidak terupdate menjadikannya mustahil digunakan sebagai dasar perumusan kebijakan terkait penanganan masalah kependudukan.

Elemen data Jumlah Penduduk Berumur 15 Tahun Keatas Menurut Kelompok Umur dan Lapangan Usaha Utama tercatat sebagai elemen data yang paling sedikit diupdate oleh Kampung KB. Hanya terdapat tujuh Kampung KB atau $16,67 \%$ yang mampu mengupdate elemen data tersebut. Sebaliknya, elemen data Jumlah Penduduk Menurut Umur dan Jenis Kelamin tercatat paling banyak diupdate oleh Kampung KB, tercatat elemen data tersebut mampu diperbaharui oleh 31 Kampung KB atau $73,81 \%$.

Dilihat dari ruang lingkup datanya, tidak semua elemen data mampu diperbaharui. Elemen data yang terkait dengan Data Sektoral dan Administrasi Kependudukan menjadi elemen data yang paling jarang diupdate oleh Kampung KB. Adapun elemen data yang terkait dengan Data
Pendataan Keluarga tercatat paling banyak diupdate oleh Kampung KB.

Variasi keterbaharuan data juga terjadi pada Rumah Dataku yang ada. Rumah Data Krajan memiliki tingkat keterbaharuan data yang cukup tinggi. Sebanyak 28 elemen data atau $77,78 \%$ telah dilakukan updating. Sebaliknya, Rumah Data Gelang tercatat memiliki tingkat keterbaharuan data paling rendah. Hanya dua elemen data saja atau $5,56 \%$ yang mampu diperbaharui; sisanya sebanyak $94,44 \%$ elemen data yang tersedia dan disajikan dalam kondisi belum terupdate. Adapun Rumah Data Grogol memiliki tingkat keterbaharuan data yang cukup. Dari 36 elemen data yang harus diupdate oleh Rumah Data Kependudukan, sebanyak 26 elemen data atau $72,22 \%$ telah diupdate.

Dilihat dari ruang lingkup data pada Rumah Dataku yang dilakukan pembaharuan/updating, ketiganya memiliki karakteristik yang berbeda.

Tabel 3

Komposisi Keterbaharuan Elemen Data pada Rumah Dataku di Kabupaten Sidoarjo Berdasarkan Ruang Lingkup Data Tahun 2019

\begin{tabular}{|c|c|c|c|c|}
\hline \multirow{2}{*}{$\begin{array}{c}\text { Ruang Lingkup } \\
\text { Data }\end{array}$} & \multicolumn{4}{|c|}{ Jumlah Ketersediaan Elemen Data } \\
\hline & Standar & $\begin{array}{c}\text { RD } \\
\text { Krajan }\end{array}$ & $\begin{array}{c}\text { RD } \\
\text { Gelang }\end{array}$ & $\begin{array}{c}\text { RD } \\
\text { Grogol }\end{array}$ \\
\hline $\begin{array}{l}\text { Data } \\
\text { Pendataan } \\
\text { Keluarga }\end{array}$ & 21 & 19 & 0 & 16 \\
\hline $\begin{array}{l}\text { Data Potensi } \\
\text { Desa }\end{array}$ & 3 & 1 & 0 & 3 \\
\hline Data Sektoral & 6 & 4 & 2 & 4 \\
\hline $\begin{array}{l}\text { Data Adm. } \\
\text { Kependudukan }\end{array}$ & 6 & 4 & 0 & 3 \\
\hline Jumlah & 36 & 28 & 2 & 26 \\
\hline
\end{tabular}

Sumber : Data Diolah

Memperhatikan tabel di atas, keterbaharuan elemen data pada Rumah Data Krajan masih tercatat yang terbaik untuk semua ruang lingkup data. Sebaliknya, keterbaharuan elemen data pada Rumah Data Gelang tercatat paling memprihatinkan, di mana hanya pada ruang lingkup data sektoral yang mampu diupdate. Selain itu, dari enam 
elemen data yang ada ternyata hanya dua elemen yang mampu diupdate.

Memperhatikan

gambaran

Kampung KB dan Rumah Dataku di atas, terlihat bahwa pengelolaan data kependudukan dan keluarga masih belum terlalu menggembirakan. Hal ini terlihat dari persentase pengelolaan Rumah Dataku yang terus mengalami penurunan antara ketersediaan data, penyajian data hingga keterbaharuan data. Kinerja pengurus masih perlu ditingkatkan. Sekalipun memiliki kepengurusan yang lengkap, mereka ternyata tidak memberikan dampak yang signifikan terhadap kualitas pengelolaan data pada Kampung KB maupun Rumah Dataku di Kabupaten Sidoarjo.

\section{Tantangan Pengembangan Rumah Data Kependudukan di Kabupaten Sidoarjo}

Memperhatikan gambaran pengelolaan data pada Kampung KB maupun Rumah Dataku di Kabupaten Sidoarjo yang belum memuaskan, Pemerintah Kabupaten Sidoarjo perlu melakukan berbagai upaya perbaikan. Salah satunya adalah mengembangkan keberadaan Rumah Dataku sebagai prasyarat bagi pembentukan Kampung KB. Berdasarkan hasil wawancara dengan pengurus Kampung KB maupun pengurus Rumah Dataku, pengembangan Rumah Dataku di Kabupaten Sidoarjo harus mampu menjawab tantangan internal dan eksternal.

Tantangan internal yang harus dihadapi dalam pengembangan Rumah Dataku terkait dengan keterbatasan anggaran dan keterbatasan sumber daya. Dalam hal ini adalah sumber daya manusia dan juga sumber daya sarana prasarana.
Pertama, keterbatasan anggaran. Sebuah masalah klasik yang sering dihadapi dalam pelaksanaan sebuah program dan kegiatan. Hal yang sama juga terjadi dalam pengelolaan data kependuduk, baik pada Kampung KB maupun Rumah Dataku. Sebagai sebuah program yang diharapkan mampu menjadi basis data dan informasi bagi intervensi pembangunan di tingkat mikro, menurut sebagian besar pengelola data masih kurang mendapat dukungan anggaran yang memadai.

Mereka menganggap selama ini belum terdapat anggaran khusus yang berkaitan dengan pengelolaan maupun operasional Rumah Dataku. Dampaknya belum semua Kampung KB yang ada di Kabupaten Sidoarjo memiliki Rumah Data Kependudukan. Bahkan Kampung KB yang telah memiliki Rumah Dataku juga mengharapkan adanya anggaran yang memadai.

Sebagaimana diketahui dalam pengumpulan, pengolahan dan penyajian data tentu tidak dapat dilakukan jika tanpa adanya dukungan anggaran yang memadai. Seandainya proses pengumpulan dan pengolahan data pada Rumah Dataku dapat dilakukan tanpa adanya biaya, namun penyajian data tersebut tentu memerlukan adanya anggaran.

Anggaran menjadi salah satu faktor penting bagi keberhasilan Rumah Dataku sebagai bagian penting dari program Kampung KB. Hal ini senada dengan pendapat Rianto, Nengsih, dan Setyadihardja (2019). Minimnya dukungan anggaran menjadi salah satu tantangan yang dihadapi program Kampung KB. Dampaknya adalah masyarakat enggan menjadi kader karena minimnya insentif atau stimulan finansial yang tersedia.

Mardani et al. (2020) juga menemukan kondisi yang sama. Salah 
satu kendala yang dihadapi oleh pelaksana lapangan Kampung KB dalam melaksanakan kegiatan adalah keterbatasan dana. Kondisi tersebut menyebabkan pelaksanaan kegiatan tidak dapat maksimal.

Pemerintah Kabupaten Sidoarjo perlu memperkuat anggaran guna mendukung pengembangan Rumah Dataku. Berkaca dari kondisi yang terjadi saat ini, anggaran untuk mendukung program Kampung KB masih dirasa kurang. Menilik Dokumen Pelaksanaan Anggaran Dinas P3AKB Kabupaten Sidoarjo, pada tahun 2019 terdapat alokasi anggaran sebesar $\mathrm{Rp}$. 128.178.000,- untuk kegiatan Rumah Dataku. Dari jumlah tersebut, lebih dari separuh $(56,17 \%)$ dialokasikan untuk kegiatan kajian. Sisanya sebesar $\mathrm{Rp}$. 56.178.000,- dialokasikan untuk kegiatan sosialisasi.

Berdasarkan data di atas, belum terdapat anggaran yang berfokus pada upaya pengembangan Rumah Dataku dan Kampung KB. Penambahan anggaran sangat diperlukan untuk mendukung berbagai upaya pengembangan Rumah Dataku sekaligus Kampung KB di Kabupaten Sidoarjo. Alokasi anggaran untuk Rumah Dataku tercatat kecil sekali, hanya 0,91\% jika dibandingkan anggaran Dinas P3AKB Kabupaten Sidoarjo sebesar Rp. 14.039.684.129,50,- pada tahun 2019

Kedua, keterbatasan sumber daya, baik sumber daya manusia maupun sumber daya berupa sarana prasarana pendukung. Keterbatasan sumber daya manusia tidak hanya dari aspek kuantitas tetapi juga kualitas. Keterbatasan kuantitas sumber daya manusia terlihat dari belum terpenuhinya semua elemen struktur organisasi Kampung KB. Meskipun untuk Rumah Dataku yang sudah ada telah memenuhi kelengkapan struktur organisasi, tetapi masih ditemukan beberapa Kampung KB yang hanya memiliki ketua serta wakil ketua untuk menangani pengelolaan data kependudukan.

Keterbatasan kualitas sumber daya manusia dapat dilihat dari pengolahan data kependudukan. Data yang berhasil dikumpulkan oleh Kampung KB dan Rumah Dataku umumnya disajikan dalam bentuk tabulasi. Sedikit sekali data yang dikumpulkan tersebut diolah dan disajikan dalam bentuk grafik maupun diagram apalagi dalam bentuk peta tematik. Kondisi ini diakibatkan oleh keterbatasan kualitas sumber daya manusia pengelola Rumah Dataku maupun Kampung KB terlebih untuk jabatan Seksi Pengolahan dan Analisis Data.

Seksi Pengolahan dan Analisis Data bertanggungjawab terhadap pengolahan dan analisa terhadap datadata yang berhasil dikumpulkan. Memperhatikan tanggungjawab yang cukup berat, maka pengampu jabatan ini diharapkan memiliki kemampuan untuk membuat grafik, diagram serta peta tematik sebagai salah satu bentuk analisa paling dasar. Jauh menjadi lebih jika mereka juga memiliki kemampuan analisis teoritis. Menjadi tantangan tersendiri bagi Pemerintah Kabupaten Sidoarjo melaui instansi terkait untuk melakukan pemenuhan sumber daya manusia pada Rumah Dataku, baik dari segi kuantitas terlebih pada segi kualitasnya.

Temuan Sari, Raikhani, Yunas, dan Hariastuti (2018) sejalan dengan tantangan di atas. Menurut mereka variabel sumber daya secara parsial berpengaruh besar terhadap keberhasilan program Kampung KB. Hasil analisis regresi linier sederhana mendapatkan nilai 0,885 untuk varibel sumber daya. Rahman \& Indrawadi (2019) juga mengungkapkan hal serupa. Menurut mereka keterbatasan 
pengetahuan kader menjadi salah satu kendala dalam implementasi program Kampung KB.

Tantangan lain terkait dengan keterbatasan sumber daya adalah minimnya sarana dan prasarana pendukung. Kondisi ini dikeluhkan oleh sebagian besar pengurus Kampung KB maupun Rumah Dataku yang sudah ada. Sarana prasarana yang banyak dikeluhkan adalah terkait dengan penyediaan Rumah Dataku itu sendiri. Keberadaan bangunan kantor menurut Rianto et al. (2019) merupakan salah satu indikator input yang sangat penting bagi keberhasilan program KKBPK di Kampung KB. Rumah Dataku merupakan salah satu implementasi dari program KKBPK.

Sarana prasarana pendukung lain yang banyak dikeluhkan umumnya berkaitan dengan pengolahan dan penyajian data kependudukan yang berhasil dihimpun. Dampak langsung yang dapat dirasakan adalah banyak pengelolaan data kependudukan dilakukan secara manual. Padahal di era revolusi industri 4.0 ini keberadaan teknologi informasi telah menjadi sebuah keharusan untuk mempermudah kehidupan manusia, termasuk dalam hal mengolah data kependudukan.

Tanpa adanya dukungan sarana prasarana baik fisik maupun teknologi maka Rumah Dataku akan mengalami kesulitan untuk dapat menunjukkan eksistentinya sekaligus untuk memberikan manfaat bagi masyarakat. Kondisi ini senada dengan temuan Hoeriah (2019) bahwa implementasi program Kampung KB terkendala oleh permasalahan kurangnya sarana prasarana dalam menjalankan program Kampung KB.

Apabila Pemerintah Kabupaten Sidoarjo berkomitmen untuk mengembangkan Rumah Dataku, maka pemenuhan sumber daya manusia yang berkualitas dan sarana prasarana pendukung yang memadai menjadi tantangan tersendiri. Pengembangan Rumah Dataku di Kabupaten Sidoarjo harus dibarengi dengan kebijakan penyediaan sumber daya manusia yang mumpuni. Setidaknya terdapat pengurus Rumah Dataku yang menguasai statistik dan permasalahan kependudukan. Pemerintah Kabupaten Sidoarjo juga diharapkan dapat memenuhi kebutuhan sarana prasana yang mendukung operasional Rumah Dataku.

Tantangan selanjutnya yang dihadapi dalam pengembangan Rumah Dataku adalah tantangan eskternal. Tantangan ini terkait dengan perkembangan lingkungan yang terjadi. Lingkungan ini juga harus mendapat perhatian agar keberadaan Rumah Dataku dapat memberikan dampak yang signifikan.

Pertama, belum optimalnya koordinasi. Dalam hal ini adalah koordinasi antar sesama pengurus maupun pengurus dengan pihak lain. Kondisi ini memiliki keterkaitan yang sangat erat dengan masih kurangnya pemahaman berbagai pihak mengenai posisi dan peran penting Rumah Dataku.

Koordinasi merupakan sebuah kata yang sangat mudah diucapkan namun sangat sulit direalisasikan. Demikian pula yang terjadi dengan pengelolaan Rumah Dataku di Kabupaten Sidoarjo. Salah satu contoh adalah belum optimalnya koordinasi Rumah Dataku dengan pemerintah Desa/Kelurahan. Hal ini terlihat dari minimnya data terkait potensi desa/kelurahan yang disediakan, disajikan hingga diupdate oleh Rumah Dataku maupun Kampung KB.

Belum optimalnya koordinasi dengan pihak lain khususnya pemerintah desa tentu akan 
berpengaruh terhadap kegiatan Rumah Dataku maupun Kampung KB. Salah satunya adalah ketiadaan dukungan dari pihak lain, khususnya pemerintah. Padahal di sisi lain, Rumah Dataku memiliki peran untuk mensinergikan komponen BKKBN dengan mitra kerja yang ada.

Kondisi tersebut sejalan dengan temuan Rahman \& Indrawadi (2019) yang menunjukan belum maksimalnya dukungan pemerintah dalam implementasi program Kampung KB. Dampaknya program tersebut kurang optimal dalam meningkatkan kesejahteraan masyarakat. Hal yang sama juga disampaikan oleh Nurjannah dan Susanti (2018) serta Hoeriah (2019). Mereka menemukan bahwa belum terjalin kerjasama yang baik dari sisi pelaksanaan program Kampung KB.

Pentingnya dukungan pemerintah dalam pengembangan Rumah Dataku juga dijelaskan oleh Anggraeni, Afifuddin, dan Suyeno (2020). Salah satu faktor pendukung keberhasilan implementasi Kampung KB di Kabupaten Mojokerto adalah dukungan yang besar dari pemerintah. Adanya dukungan dari pemerintah, baik pusat maupun daerah telah mendorong pelaksanaan program Kampung KB.

Rumah Dataku juga akan merasakan dampak positif yang sama ketika mendapat dukungan dari berbagai pihak, khususnya pemerintah di semua level. Dukungan dari pemerintah secara tidak langsung juga menjamin ketersediaan dukungan anggaran hingga sumber daya sebagaimana disampaikan Septi (2019). Salah satu faktor yang mendukung keberhasilan Kampung KB Jasem adalah networking yang baik. Kondisi tersebut berkontribusi terhadap adanya dukungan anggaran dan komitmen di Kampung KB Jasem.
Rumah Dataku sebagai bagian tidak terpisahkan dari Kampung KB dengan demikian juga bergantung pada kualitas networking yang dibangun.

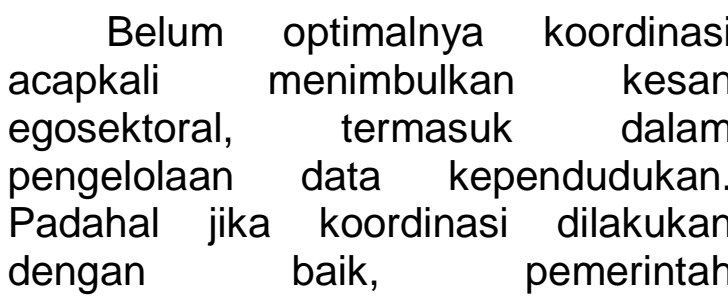
desa/kelurahan dipastikan juga terbantu dengan keberadaan Rumah Dataku. Pemerintah desa/kelurahan maupun pihak lain yang berkepentingan dengan keberadaan data kependudukan dapat menambahkan kebutuhan data mereka kepada pengurus Rumah Dataku untuk dilakukan inventarisasi.

Bagi pengurus Rumah Dataku, adanya koordinasi yang baik maka eksistensi mereka akan didukung oleh masyarakat. Tugas berat inilah yang diemban oleh Seksi Pelayanan dan Pemanfaatan Data. Jabatan ini diharapkan diisi oleh mereka yang memiliki kemampuan komunikasi dan koordinasi yang baik.

Mardiyono (2017) juga menekankan pentingnya koordinasi lintas sektor bagi keberhasilan program Kampung KB. Melalui koordinasi yang baik maka Kampung KB diharapkan menjadi gerakan budaya yang dilaksanakan secara kolektif dan berkesinambungan. Dengan demikian, Kampung KB akan dianggap sebagai prakarsa masyarakat dibanding sebagai program pemerintah.

Pemerintah Kabupaten Sidoarjo, melalui Dinas P3AKB diharapkan terus meningkatkan koordinasi guna mengembangkan Rumah Data Kependudukan. Dinas P3AKB diharapkan mampu mendorong Bupati Sidoarjo untuk berperan aktif bersama Tim Pokja Kampung KB termasuk melibatkan legislatif guna 
mengagendakan intervensi program sekaligus menjaga kesinambungan program. Rumah Data Kependudukan dapat dijadikan salah satu program intervasi yang diagendakan.

Kedua, minimnya pemahaman dan partisipasi masyarakat. Dalam hal ini adalah pemahaman mengenai pentingnya peran Rumah Dataku dalam menyediakan data kependudukan yang valid dan dapat dipertanggungjawabkan. Kurangnya pemahaman mereka terhadap hal tersebut dapat dilihat dari masih minimnya keberadaan Rumah Dataku di Kabupaten Sidoarjo. Bahkan andaipun sudah terdapat Rumah Dataku, mereka belum mampu menyediakan data kependudukan dengan optimal.

Masih minimnya dukungan tokoh masyarakat maupun Pemerintah Desa/Kelurahan terhadap keberlangsungan Rumah Dataku menjadi salah satu indikator awal. Tanpa adanya dukungan yang optimal maka dapat dipastikan eksistensi Rumah Dataku di masyarakat akan menemui kesulitan baik dari tata kelola data maupun operasional. Kondisi di atas juga memperlihatkan bahwa sosialisasi yang selama ini dilakukan nampaknya masih belum optimal.

Pentingnya peran serta masyarakat dalam mendukung keberhasilan sebuah program dikemukakan oleh Ali, Junaidi, dan Hafiz (2019). Implementasi program Desa KB menurut mereka terkendala oleh rendahnya partisipasi masyarakat. Hal ini juga sedikit banyak disebabkan oleh kurangnya pemahaman pemangku kepentingan di setiap level tentang konsep Kampung KB.

$\begin{array}{llr}\text { Pendapat } & \text { yang } & \text { sama } \\ \text { disampaikan oleh } & \text { Nurjannah dan } \\ \text { Susanti (2018). Penelitian yang }\end{array}$ mereka lakukan menemukan bahwa kurang antusiasnya masyarakat dalam mendukung Kampung KB disebabkan oleh pemahaman yang kurang. Masyarakat sebenarnya telah memiliki pengetahuan dan pemahaman tentang Kampung KB tapi masih terbatas (Rianto et al., 2019). Program Kampung KB masih dipersepsikan sebagai program pengendalian jumlah anak serta identik dengan alat kontrasepsi. Masih sedikit masyarakat yang memahaminya dari aspek kependudukan, pembangunan keluarga maupun aspek lintas sektor.

\section{Pengembangan Rumah Dataku di Kabupaten Sidoarjo dalam} mendukung Kampung KB tentu harus diikuti oleh pemahaman yang baik dari masyarakat. Tantangan inilah yang juga harus diperhatikan oleh Pemerintah Kabupaten Sidoarjo. Mengingat perbaikan pemahaman masyarakat tentu secara langsung akan meningkatkan partisipasi mereka dalam mendukung keberlangsungan program.

Peningkatkan pemahaman masyarakat tentu sangat bergantung pada kegiatan yang dilaksanakan di Kampung KB (Rianto et al., 2019). Semakin banyak kegiatan yang dilaksanakan pada Kampung KB, maka penyuluh lapangan dapat semakin intens untuk mengedukasi masyarakat. Salah satu materi yang dapat diedukasikan kepada masyarakat adalah peran penting Rumah Dataku. Menjadi tugas bagi Pemerintah Kabupaten Sidoarjo untuk memastikan bahwa kegiatan Kampung KB berjalan dengan baik. Bentuk dukungan yang diberikan dapat berupa alokasi anggaran dan peningkatan kualitas penyuluh lapangan maupun media sosialisasi.

\section{KESIMPULAN}

Berdasarkan uraian sebelumnya terlihat bahwa kondisi Rumah Dataku 
di Kabupaten Sidoarjo masih jauh dari harapan. Sebagai prasyarat pembentukan Kampung KB, ternyata di Kabupaten Sidoarjo hanya terdapat tiga Rumah Dataku. Dibandingkan dengan jumlah Kampung KB yang mencapai 42 unit, maka Rumah Data Kependudukan hanya sebesar $7 \%$. Dilihat dari tiga aspek pengelolaan data yaitu penyediaan data, penyajian data hingga keterbaharuan data. Kondisi pengelolaan data kependudukan juga belum optimal. Persentase dari ketiga alur pengelolaan data tersebut terus mengalami menurun.

Pengembangan Rumah Dataku di Kabupaten Sidoarjo menghadapi tantangan internal dan eksternal. Terbatasnya alokasi anggaran serta minimnya sumber daya manusia dan sarana prasarana menjadi tantang internal yang harus dihadapi. Sedangkan tantang eksternal yang dihadapi adalah kurang optimalnya koordinasi serta minimnya pemahaman dan partisipasi masyarakat.

\section{REKOMENDASI}

Memperhatikan beberapa tantangan di atas, Pemerintah Kabupaten Sidoarjo perlu mengambil beberapa langkah guna mengembangkan Rumah Dataku. Pertama, Pemerintah Kabupaten Sidoarjo perlu menambah porsi alokasi anggaran untuk pengembangan Rumah Dataku. Alokasi anggaran sebesar 0,91\% dari keseluruhan anggaran Dinas P3AKB menjadikan pengembangan Rumah Dataku menjadi berat. Selain penambahan porsi, Pemerintah Kabupaten Sidoarjo juga harus memastikan bahwa anggaran tersebut benar-benar digunakan untuk pengembangan Rumah Dataku. Salah satunya Pemerintah Kabupaten Sidoarjo dapat mengadakan kompetisi antar Kampung KB. Salah satu aspek yang dikompetisikan adalah kondisi Rumah Dataku. Harapannya Desa/Kelurahan di Kabupaten Sidoarjo terdorong untuk membentuk Kampung KB dan mengembangkan Rumah Dataku.

Kedua, Pemerintah Kabupaten Sidoarjo perlu meningkat kuantitas dan kualitas sumber daya Rumah Dataku, baik sumber daya manusia maupun sarana prasarana. Terkait dengan sumber daya manusia, Pemerintah Kabupaten Sidoarjo dapat melakukan bimbingan teknis terhadap pengurus Rumah Dataku maupun Kampung KB. Pemerintah Kabupaten Sidoarjo juga dapat menggandeng dunia akademis untuk meningkatkan kualitas pengolahan data kependudukan pada Rumah Dataku. Salah satunya melalui kegiatan KKN Tematik, dengan demikian mahasiswa yang melakukan KKN melakukan transfer of knowledge kepada pengurus Rumah Dataku maupun Kampung KB. Terkait dengan sarana prasarana, Pemerintah Kabupaten Sidoarjo perlu membuat sebuah aplikasi yang dapat membantu proses pengumpulan dan pengolahan data kependudukan.

Ketiga, meningkatkan komunikasi dan koordinasi Rumah Dataku dengan stakeholder terkait. Salah satu hal yang penting untuk ditingkatkan adalah komunikasi dan koordinasi dengan Pemerintah Desa/Kelurahan. Rumah Dataku diharapkan dapat memberikan kontribusi kepada Desa/Kelurahan sebagai produsen data. Pemerintah Kabupaten Sidoarjo juga perlu meningkatkan peran aktif Tim Pokja Kampung KB Kabupaten Sidoarjo. Harapannya kualitas koordinasi dan komunikasi lintas sektor yang dibutuhkan dalam pengembangan Rumah Dataku sebagai bagian penting Kampung KB dapat ditingkatkan. 
Keempat, Pemerintah Kabupaten Sidoarjo perlu meningkatkan pemahaman dan peran serta masyarakat terkait Rumah Dataku sekaligus bagian yang penting dari Kampung KB. Hal ini dapat dilakukan dengan meningkatkan kualitas pengurus Kampung KB maupun penyuluh KB. Mereka inilah yang akan memegang peranan penting dalam memberikan pemahaman sekaligus mengajak berpartisipasi dalam pengelolaan Rumah Dataku maupun Kampung KB di Kabupaten Sidoarjo.

\section{UCAPAN TERIMA KASIH}

Terima kasih penulis sampaikan kepada Pemerintah Kabupaten Sidoarjo, khususnya Dinas P3AKB Kabupaten Sidoarjo yang telah memberikan dukungan data. Ucapan terima kasih juga penulis sampaikan kepada Bappeda Kabupaten Sidoarjo.

\section{DAFTAR PUSTAKA}

Ali, M., Junaidi, M., \& Hafiz, A. (2019). Implementasi Program Desa Keluarga Berencana Bagi Kesejahteraan Masyarakat Studi Kasus Geguntur Mataram. Jurnal Ulul Albab, 23(2), 95-99.

Anggraeni, N., Afifuddin, \& Suyeno. (2020). Implementasi Program Kampung Keluarga Berencana Dalam Meningkatkan Kualitas Hidup Masyarakat (Studi Kasus Desa Sumberkarang Kabupaten Mojokerto). Jurnal Respon Publik, 14(1), 32-41.

Bachtiyar, N. A., \& Wibawani, S. (2017). Implementasi Program Kampung Keluarga Berencana Di Dusun Ambeng-Ambeng Desa Ngingas Kecamatan Waru Kabupaten Sidoarjo. Dinamika Governance: Jurnal IImu Administrasi Negara, 7(1), 13-26. https://doi.org/10.33005/jdg.v7i1.1 194

BKKBN. (2018). Panduan Rumah Data Kependudukan di Kampung KB (Model Solusi Strategis Pengendalian Dampak Kependudukan). Jakarta: Direktorat Analisis Dampak Kependudukan Badan Kependudukan dan Keluarga Berencana Nasional.

Hoeriah, R. (2019). Implementasi Program Kampung Keluarga Berencana (KB) di Kampung Kaliwadas Kelurahan Lopang Kecamatan Serang Kota Serang Provinsi Banten. Universitas Sultan Ageng Tirtayasa.

Istianda, M., Wulandari, F. R., Purwanto, A. J., Putra, M. B., \& Darmanto. (2014). Pengembangan Organisasi. Jakarta: Universitas Terbuka.

Mardani, N. K. T., Winaya, I. K., \& Purnamaningsih, P. E. (2020). Evaluasi Program Kampung Keluarga Berencana di Kota Denpasar. Jurnal IImu Administrasi Negara, 1(1), 1-8.

Mardiya. (2019, August 1). Urgensi dan Manfaat Rumah Dataku. Retrieved September 21, 2019, from HarianJogja.com website: https://opini.harianjogja.com/read/ 2019/08/01/543/1009270/opiniurgensi-dan-manfaat-rumahdataku

Mardiyono. (2017). Kampung KB Sebagai Upaya Pemberdayaan Masyarakat/ Keluarga di Jawa Timur (Studi di Kota Malang dan Kabupaten Bondowoso). Jurnal Cakrawala, 11(2), 129-136. Retrieved from http://cakrawalajournal.org/index.p hp/cakrawala/article/viewFile/13/1 3 
Nurjannah, S. N., \& Susanti, E. (2018). Implementasi Program Kampung Keluarga Berencana (KB) di Kabupaten Kuningan Tahun 2018 (Studi Kuantitatif Dan Kualitatif). Jurnal IImu Kesehatan Bhakti Husada: Health Sciences Journal, 9(2), $\quad$ 78-85. https://doi.org/10.34305/jikbh.v9i2. 64

Rahman, H., \& Indrawadi, J. (2019). Implementasi Program Kampung KB dalam Meningkatkan Kesejahteraan Masyarakat di Kelurahan Gunung Pangilun Kecamatan Padang Utara Kota Padang. Journal of Civic Education, 2(4), 295-301. https://doi.org/10.24036/jce.v2i4.2 33

Rianto, F., Nengsih, N. S., \& Setyadihardja, R. (2019). Evaluasi Program Kampung Keluarga Berencana di Kota Tanjungpinang. Dimensi, 8(2), 286-306.

Sari, L. R., Raikhani, A., Yunas, N. S., \& Hariastuti, I. (2018). Analisis Faktor Yang Mempengaruhi Keberhasilan Program Kampung KB Di Kabupaten Jombang. JPEKBM (Jurnal Pendidikan Ekonomi, Kewirausahaan, Bisnis Dan Manajemen), 2(2), 83. https://doi.org/10.32682/jpekbm.v2 i2.999

Septi. (2019). Keberhasilan Kampung $K B$ Jasem Dalam Program Kependudukan, Keluarga Berencana dan Pembangunan
Keluarga (KKBPK). Universitas Islam Negeri Sunan Kalijaga.

Sulaksana, U. (2004). Manajemen Perubahan. Yogyakarta: Pustaka Pelajar.

Wijayanto. (2019, June 13). Pemkab Lakukan Upaya Pengembangan Kampung KB di Ngingas. Retrieved September 21, 2019, from JawaPos.com website: https://radarsurabaya.jawapos.co $\mathrm{m} / \mathrm{read} / 2019 / 06 / 13 / 141129 /$ pemka b-lakukan-upaya-pengembangankampung-kb-di-ngingas 